\title{
Microbiological study of naturally fermented Algerian green olives: isolation and identification of lactic acid bacteria and yeasts along with the effects of brine solutions obtained at the end of olive fermentation on Lactobacillus plantarum growth
}

\author{
By Kacem Mourad and Karam Nour-Eddine
}

\author{
Laboratoire de Biologie des Microorganismes et Biotechnologie, Faculté des Sciences, \\ Université d'Oran, Algérie \\ Correspondence to: KACEM Mourad, B.P. 8053 SIDI El-BACHIR, 31026, Oran, Algérie. \\ E-mail: mourad.kacem1@ caramail.com
}

\section{RESUMEN}

Estudios microbiológicos de aceitunas verdes argelinas fermentadas naturalmente: aislamiento e identificación de bacterias lácticas y levaduras, y efecto de las soluciones de salmuera obtenidas al final de fermentación sobre el crecimiento de Lactobacillus plantarum

La microflora de las aceitunas verdes fermentadas naturalmente elaboradas en Argelia Occidental fue estudiada en períodos de fermentación de 15, 60 y 90 días. Diferentes microorganismos (bacterias aeróbicas, coliformes, estafilococos, bacterias del ácido láctico, lactobacilos, enterococos, levaduras, psicotrofos y bacterias lipolíticas) fueron detectados a los 15 y 60 días de fermentación. Después de 90 días de fermentación ( $\mathrm{pH} 4.40)$, la población de bacterias lácticas se hizo dominante y persistió junto con las levaduras a lo largo de todo el proceso. Las bacterias lácticas aisladas (343) fueron identificadas como $L$. casei, $L$. rhamnosus, $L$. paracasei, L. plantarum, L. lactis subsp. lactis, E. faecalis, E. faecium y E. durans. La especie dominante fue $L$. plantarum. Las levaduras aisladas (32) de todas las muestras fueron identificadas como Saccharomyces cerevisiae o Candida parapsilosis. También se recoge en este estudio que las soluciones de salmuera obtenidas al final de fermentación de aceitunas verdes fueron capaces de estimular el crecimiento de varias cepas de L. plantarum.

PALABRAS-CLAVE: Aceitunas fermentadas - Bacterias lácticas - Lactobacillus plantarum - - Levaduras - Microbiología.

\section{SUMMARY}

Microbiological study of naturally fermented Algerian green olives: isolation and identification of lactic acid bacteria and yeasts along with the effects of brine solutions obtained at the end of olive fermentation on Lactobacillus plantarum growth

The microflora of naturally fermented green olives produced in Western Algeria was studied over 15,60 and 90 day fermentation periods. Different microorganisms (aerobic bacteria, coliforms, staphylococci, lactic acid bacteria, lactobacilli, enterococci, yeasts, psychrotrophs and lipolytic bacteria) were recorded at 15 and 60 days of fermentation.
After 90 days $(\mathrm{pH} \mathrm{4.40)}$ of fermentation, the lactic acid bacteria population became dominant and persisted together with yeasts throughout the fermentation period.

The lactic acid bacteria isolated (343 isolates) were identified as $L$. casei, L. rhamnosus, $L$. paracasei, $L$. plantarum, L. lactis subsp. lactis, E. faecalis, E. faecium and $E$. durans. The dominant species was $L$. plantarum. Yeasts were isolated from all samples (32 isolates) and were identified as Saccharomyces cerevisiae or Candida parapsilosis. Also, in this study we reported that brine solutions obtained at the end of olive fermentation were able to stimulate the growth of several L. plantarum strains.

KEY-WORDS: Fermented olives - Lactic acid bacteria Lactobacillus plantarum - Microbiology - Yeasts.

\section{INTRODUCTION}

Olives (zaitun) (aceituna in Spanish) are one of the major agricultural products in Algeria. With an area of $2,400,000 \mathrm{~km}^{2}$, olive groves occupy a total area of 165,800 hectares distributed essentially in mountainous areas (Anonymous, 2000). More than $48 \%$ of the Segoise variety of olives are harvested in their green state and processed according to the traditional technique for fermenting green olives. For example, in many regions of Western Algeria (Sig, Remchi, Tlemcen, etc.), olives are fermented as follows: green olives are placed in 1 to $2 \%(\mathrm{w} / \mathrm{v})$ sodium hydroxide (lye) solution until the lye penetrates the flesh. Cold water is then added to the solution to remove the lye. Olives are then placed in barrels with a 4 to $6 \%$ brine solution and allowed to undergo a spontaneous fermentation under ambient temperature (22 to $24^{\circ} \mathrm{C}$ ). The fermentation period usually takes between two and three months.

This product is consumed traditionally as a base for soup, eaten as pickles or mixed with bread and spices according to local tastes and traditions.

No measures whatsoever are taken to control fermentation, which in most cases is incomplete or 
affected by microbial spoilage. Therefore, it is not always easy or feasible to control undesirable pathogens or micro organisms causing spoilage in the olives that can cause disease in the Algerian mountaineer population who live in primitive conditions with poor sanitation. In addition, olive fermentation is carried out without starter cultures and therefore the quality of the final product is frequently inconsistent. For these reasons greater attention must be given to quality control in the fermenting of olives.

The availability of information on the microbiological characteristics of natural microflora present in olives is limited to few reports. Microbiological studies show that several species of lactic acid bacteria and yeasts are present and some of them were prevalent throughout the fermentation period with a particular metabolic capability (Ruiz-Barba and Jiménez-Díaz, 1994; Asehraou et al., 2000; Catulo et al., 2002).

Lactic acid bacteria and yeasts developed their activity during the last fermentation phases (Fernández-Díez, 1983; Ruiz-Barba and JiménezDíaz, 1995, Oliveira et al., 2004). Borcakli et al. (1993a) reported that the microbial flora of fermented olives are mainly composed of Gram-negative bacteria and yeasts, while $L$. plantarum and Pediococcus sp. are detected only after 76 days of fermentation.
As far as we know, lactic acid bacteria has long been described as being auxotrophic for many vitamins (Rogosa et al., 1961; Kandler and Weiss, 1986), and a number of wild-type L. plantarum strains isolated from the fermentation of green olives have been shown to require vitamins as growth factors (Ruiz-Barba and Jimenez-Diaz, 1994). Lacking some of these factors can dramatically affect the growth rate or even the survival of $L$. plantarum strains. Yeasts present in vegetable fermentation play a beneficial role, which is important in terms of $L$. plantarum nutritional requirements.

During the last decades, progressive attention has being given to the isolation and identification of lactic acid bacteria from fermented olives, due the beneficial impact of starter cultures used in olive fermentation. The main species of lactic acid bacteria isolated from different fermented olives produced in many Mediterranean regions can be observed in Table 1.

Recent work concerning lactic acid bacteria isolated from the spontaneous fermentation of green olives has been carried out by Kacem et al. (2004a) in Algeria. In this study, Lactococcus lactis, $L$. plantarum and $E$. faecalis species were isolated and identified according to morphological and biochemical criteria.

Until now, no analytical study has taken place on naturally fermented Algerian olives to evaluate their

Table 1

Lactic acid bacteria isolated from olives

\begin{tabular}{|c|c|c|}
\hline Authors & Products & Lactic acid bacteria \\
\hline Floriano et al. (1998) & Spanish-style green olive & $\begin{array}{l}\text { L. plantarum } \\
\text { Enterococcus sp. }\end{array}$ \\
\hline Maldonado et al. $(2002,2003)$ & Fermented green olive of South Spain & L. plantarum \\
\hline $\begin{array}{l}\text { Ruiz-Barba et al. (1991); Ruiz-Barba } \\
\text { and Jiménez-Díaz (1994, 1995) }\end{array}$ & Spanish fermented olives & L. plantarum \\
\hline $\begin{array}{l}\text { Fernández-Díez (1983); Van } \\
\text { Den Berg et al. (1993), } \\
\text { Oliveira et al. (1993) }\end{array}$ & Portuguese fermented olives & $\begin{array}{l}\text { L. plantarum } \\
\text { L. paracasei } \\
\text { L. pentosus } \\
\text { Ln. pentosaceus }\end{array}$ \\
\hline Asehraou et al. (2002) & Moroccan fermented olives & L. plantarum \\
\hline Borcakli et al. (1993) & Turkish fermented olives & L. plantarum \\
\hline Kacem et al. (2004a) & Algerian fermented olives & $\begin{array}{l}\text { L. lactis } \\
\text { L. plantarum } \\
\text { E. faecalis }\end{array}$ \\
\hline Korukluoglu et al. (2002) & Turkish fresh olives & $\begin{array}{l}\text { L. plantarum } \\
\text { L. brevis } \\
\text { L. lactis } \\
\text { Ln. mesenteroides } \\
\text { P. damnosus }\end{array}$ \\
\hline Randazzo et al. ( 2004) & Sicilian (Italy) fermented green olives & $\begin{array}{l}\text { L. casei } \\
\text { L. plantarum } \\
\text { L. brevis } \\
\text { E. faecium }\end{array}$ \\
\hline
\end{tabular}


microbiological profile. The knowledge of bacterial flora present in olive fermentation is very important for predicting and determining the quality of the final fermented olive.

This study describes the microbiological changes occurring during the fermentation of green olives produced in Western Algeria with special reference to the changes in lactic acid bacteria and yeasts. In this study we also report the ability of brine solutions obtained at the end of olive fermentation to stimulate the growth of $L$. plantarum.

\section{MATERIAL AND METHODS}

\subsection{Olive samples}

Traditionally fermented green olives (Sigoise variety) were obtained from a domestic factory located in Sig (Western Algeria). Four lots (barrels of $60 \mathrm{Kg}$ of olives in $40 \mathrm{~L}$ of brine, $\mathrm{NaCl} 6 \% \mathrm{w} / \mathrm{v}$ ) were analyzed from December to March (2003) after 15, 60 and 90 days of fermentation. In addition to brine solution samples obtained after 90 days from barrels, 14 other brine solution samples were obtained from different olive fermentations in the same region. These brine solutions were used for a stimulation study.

\subsection{Microbiological and physicochemical analyses}

In this study, the olives were used for microbiological analyses and brines for $\mathrm{pH}$ measurement. Fifty grams of olives were removed from each barrel (after 15, 60 and 90 days of fermentation), pitted with a hand-operated pitting machine, homogenized with $10 \mathrm{ml}$ of $1 \%(\mathrm{w} / \mathrm{v})$ sterile peptone solution and then diluted using the dilution pour-plate method. Total aerobic counts were made on plate count agar (Oxoid Ltd., UK) after incubation at $30{ }^{\circ} \mathrm{C}$ for $72 \mathrm{~h}$, and coliform counts on violet red bile agar (Oxoid) after incubation at $30{ }^{\circ} \mathrm{C}$ for $24 \mathrm{~h}$. Staphylococci were numbered on Baird-Parker medium (Oxoid) after incubation at $37{ }^{\circ} \mathrm{C}$ for $48 \mathrm{~h}$, yeasts on potato dextrose agar (Oxoid) after incubation at $22^{\circ} \mathrm{C}$ for 5 days, psychrotrophs on plate count agar incubated at $7{ }^{\circ} \mathrm{C}$ for 10 days, lipolytic bacteria on tributyrin agar (Oxoid) after incubation at $30{ }^{\circ} \mathrm{C}$ for $72 \mathrm{~h}$. Lactic acid bacteria were numbered on MRS agar (Oxoid) (de Man et al., 1960) adjusted to $\mathrm{pH} 5$ so that the growth of other microorganisms could be suppressed (Garcia et al., 1987) and lactobacilli on acetate agar (Rogosa et al., 1951) after incubation at $30{ }^{\circ} \mathrm{C}$ for 5 days under anaerobic conditions (Gas Pak System, Becton Dickinson). Enterococci were numbered on citrate acid agar after incubation at $37{ }^{\circ} \mathrm{C}$ for $72 \mathrm{~h}$ and lactococci were grown on M17 agar (Merck Mikrobiologie) (Terzaghi and Sandine, 1975) incubated at $30^{\circ} \mathrm{C}$ for $48 \mathrm{~h}$.

The $\mathrm{pH}$ of the brine solution was determined electrometrically with a pH meter (Micro pH 2002, Crison, Barcelona, Spain).
Significance of differences between means was assessed by the Student-Newman-Keul's multiple range test (Steel and Torrie, 1980) after log transformation for bacterial counts.

\subsection{Isolation and identification of isolates}

\subsubsection{Lactic acid bacteria}

Colonies (25-40 per sample) displaying the general characteristics of lactic acid bacteria were picked at random from MRS agar, acetate agar, and citrate acid agar. All the isolates were initially subjected to Gram straining, and the catalase test. Colonies and cell morphology characteristics on MRS and M17 agar were examined afterwards and then separated into phenotypic groups.

The identification of lactic acid bacteria was performed using the following tests: growth at $15^{\circ} \mathrm{C}$, $37^{\circ} \mathrm{C}$ and $45^{\circ} \mathrm{C}$ in MRS broth for 5 days and at $4{ }^{\circ} \mathrm{C}$ and $10{ }^{\circ} \mathrm{C}$ for 12 days; $\mathrm{NaCl}(4 \%, 6.5 \%$ and $8 \%)$ and $\mathrm{pH}$ (3.9 and 9.6) tolerance was performed on MRS broth; Sherman test and survival after heating at $60^{\circ} \mathrm{C}$ for $30 \mathrm{~min}$ were also studied (Samelis et al., 1994); gas production from glucose, determined in MRS broth containing inverted Durham tubes; hydrolysis of arginine, tested on MRS with bromocresol purple (Thomas, 1973); citrate utilization in the presence of carbohydrates, according to Kempler and Mc Kay (1980) and production of acetoin from glucose, determined using the Vogs-Proskauer test (Zourari et al., 1991). The identification profile adopted also took into account API 50 CHS/L galleries (BioMerieux, S.A., France).

Isolates of lactococci, enterococci and lactobacilli were identified according to the criteria of Mundt (1986), Devriese et al. (1987) and Kandler and Weiss (1986) respectively.

\subsubsection{Yeasts}

The yeast isolates were distinguished separately according to their different morphological appearance upon growth in a potato dextrose agar. After being isolated as pure cultures, the yeast isolates were identified based on the morphological and physiological criteria described by Kreger-van Rij (1984) and Barnett et al. (1990). The other biochemical tests were done with an API 20C AUX system (BioMerieux, S.A.), and readings were made at 24,48 and $72 \mathrm{~h}$ of incubation at $30^{\circ} \mathrm{C}$.

Microorganisms were maintained in sterile $\left(120^{\circ} \mathrm{C}, 10 \mathrm{~min}\right)$ reconstituted skim milk $(10 \% \mathrm{w} / \mathrm{v})$ at $4{ }^{\circ} \mathrm{C}$ or at $-20{ }^{\circ} \mathrm{C}$ in MRS broth supplemented with $20 \% \mathrm{w} / \mathrm{v}$ glycerol. Working cultures were also kept on MRS agar, M17 agar or potato dextrose agar slant at $4^{\circ} \mathrm{C}$ and streaked every four weeks.

\subsection{Stimulation study}

Besides L. plantarum strains isolated in this study, other L. plantarum strains from our collection 
(Laboratory of Biology of Microorganisms and Biotechnology, University of Oran, Algeria) were used as indicator strains.

The brine solutions $(5 \mathrm{ml})$ obtained at the end of olive fermentations was centrifuged at $12000 \mathrm{~g}$ for 15 minutes at $4{ }^{\circ} \mathrm{C}$ to remove cells. The supernatant was then filter-sterilized $(0.22-\mu \mathrm{m}$ pore size filter Gelman Acrodisc 13, Pall Corp., Ann Arbor, USA). The solution thus obtained was designated as Cell Free Brine (CFB) and stored at $4{ }^{\circ} \mathrm{C}$ and $-20^{\circ} \mathrm{C}$.

Pre-poured MRS agar plates were overlaid with $7 \mathrm{ml}$ MRS soft agar containing $0.2 \mathrm{ml}$ of indicator $(L$. plantarum) culture. In order to standardize the assay, the inoculum was approximately $10^{5}$ indicator cfu $\mathrm{ml}^{-1}$. Wells of $5 \mathrm{~mm}$ in diameter were cut onto the agar plate using a cork borer, and aliquots of $50 \mu \mathrm{l}$ from each brine solution sample (CFB) were placed into the wells. The plates were incubated for 5 days at $30^{\circ} \mathrm{C}$, and examined for the presence of turbid zones (bacterial growth) around the wells. Each assay was performed in duplicate.

\section{RESULTS}

The mean values of the $\mathrm{pH}$ of brine solutions were $5.90,4.53$ and 4.40 after 15,60 and 90 days of fermentation respectively.

Table 2 shows the counts of aerobic bacteria, coliforms, staphylococci, lactic acid bacteria, lactobacilli, enterococci, yeasts, psychrotrophs and lipolytic bacteria recorded throughout the three stages (after 15, 60 and 90 days) of naturally green olive fermentation.

High counts of aerobic bacteria and lactic acid bacteria were recorded at 60 and 90 days of fermentation. However low incidences of coliforms as well as staphylococci were detected. In contrast to lactic acid bacteria, lactobacilli and enterococci, the incidence of yeasts was lower (mean log count 1.88) after 15 days of fermentation. After 60 and 90 days of

Table 2

Mean log plate counts of different microbial groups during naturally green olive fermentation

\begin{tabular}{lccc}
\hline \multirow{2}{*}{ Microbial group } & \multicolumn{3}{c}{ Fermentation time (days) } \\
\cline { 2 - 4 } & $\mathbf{1 5}$ & $\mathbf{6 0}$ & 90 \\
\hline Total aerobic count & $4.52^{\mathrm{a}}$ & $7.76^{\mathrm{b}}$ & $6.88^{\mathrm{b}}$ \\
Coliforms & 2.12 & 2.33 & 1.96 \\
Staphylococci & 2.03 & 2.52 & 1.35 \\
Lactic acid bacteria & 3.8 & 6.55 & 6.96 \\
Lactobacilli & $3.6^{\mathrm{a}}$ & $5.55^{\mathrm{b}}$ & $5.66^{\mathrm{b}}$ \\
Enterococci & 3.6 & 4.33 & 5.65 \\
Yeasts & $1.88^{\mathrm{a}}$ & $3.84^{\mathrm{b}}$ & $5.98^{\mathrm{b}}$ \\
Psychrotrophs & 4.22 & 3.88 & 1.53 \\
Lipolytic & 3.1 & 3.56 & 2.42 \\
\hline
\end{tabular}

Values are the means of lots of naturally green olives.

a,b Means of the same organism with different superscripts differ significantly $(\mathrm{P}<0.05)$. fermentation high counts of yeasts were detected (mean log counts 3.84 and 5.98, respectively). At the end of fermentation (90 days), the levels of total lactic acid bacteria, lactobacilli, enterococci and yeasts increased to log counts $6.96,5.66,5.65$ and 5.98 respectively. In this stage of fermentation, the levels of coliforms staphylococci, psychrotrophs and lipolytic bacteria decreased to log counts 1.96, 1.35, 1.53 and 2.42 respectively.

Mean log count of aerobic bacteria was 4.52 after the first stage (15 days) and reached its peak growth to mean log counts 7.76 and 6.88 after 60 and 90 days respectively. Notably, aerobic and lactic acid bacteria were the predominant microbial group throughout the fermenting stages of the olives (Table 2).

Out of a total of 343 isolates of lactic acid bacteria obtained from fermented olives, 90 were isolated after the first stage of fermentation (15 days), 130 were isolated after the second stage (60 days) and 123 were isolated after the third stage (90 days) (Table 3 ).

The morphological, physiological and biochemical analyses of the 343 isolates revealed diversity and change in species of lactic acid bacteria during the fermentation of green olives. Bacteria were subdivided into 9 groups.

Seven groups were identified at the species level: L. casei (25 strains, $7.2 \%$ of the lactic acid bacteria isolated), L. rhamnosus (3 strains, $0.8 \%$ ), L. paracasei (27 strains, $7.8 \%)$, L. plantarum (75 strains, $21.7 \%$ ), L. confusus (7 strains, $2 \%$ ), $L$. cellobiosus (9 strains, $2.6 \%$ ), L. lactis subsp. lactis (27 strains, 7.8\%), E. faecalis (27 strains, 7.8\%), E. faecium (40 strains, $11.6 \%$ ), E. durans (26 strains, $7.5 \%$ ). Their biochemical and physiological characteristics are shown in Table IV.

Two groups were identified only at the genus level: Lactococcus sp. (41 strains, 11.8\%) and Lactobacillus sp. (36 strains, 10.4\%). All isolates grew at $15{ }^{\circ} \mathrm{C}$ but not at $45^{\circ} \mathrm{C}$ or at $6.5 \% \mathrm{NaCl}$, and had the ability to hydrolyze arginine. They produced L-Lactic acid with no gas evolution in the presence of glucose, indicating their homofermentative metabolism.

$L$. plantarum, $L$. paracasei $E$. faecium, $E$. faecalis, E. durans, L. lactis subsp. lactis species, and other Lactococcus and Lactobacillus genera were isolated in greater amounts in fermented olives. The dominant strain was $L$. plantarum species. L. plantarum and E. faecium predominated in all stages of fermentation (more frequently at 90 days), L. lactis subsp. lactis, E. faecalis or E. durans were found more frequently than $E$. faecium after 60 days; however, their proportion diminished rapidly with ageing. At the end of the fermentation period, the main species was $L$. plantarum (31.7\%) and no species of $L$. rhamnosus, $L$. confusus or $L$. cellobiosus was found. L. casei, L. paracasei and some other unidentified lactobacilli were also detected at the end of the third month of fermentation and represented $12.2 \%, 10.5 \%$ and $9.7 \%$ respectively. 
Table 3

Changes in species of lactic acid bacteria during naturally green olive fermentation

\begin{tabular}{|c|c|c|c|c|c|c|}
\hline & \multicolumn{6}{|c|}{ Fermentation time (days) } \\
\hline & \multicolumn{2}{|c|}{15} & \multicolumn{2}{|c|}{60} & \multicolumn{2}{|c|}{90} \\
\hline $\mathrm{pH}$ & \multicolumn{2}{|c|}{5.90} & \multicolumn{2}{|c|}{4.53} & \multicolumn{2}{|c|}{4.40} \\
\hline Species & No. strains & $(\%)$ & No. strains & $(\%)$ & No. strains & (\%) \\
\hline L. casei & 3 & 3.3 & 7 & 5.4 & 15 & 12.2 \\
\hline L. rhamnosus & 2 & 2.2 & 1 & 0.7 & - & - \\
\hline L. paracasei & 5 & 5.5 & 9 & 7 & 13 & 10.5 \\
\hline L. plantarum & 11 & 12.2 & 25 & 19.2 & 39 & 31.7 \\
\hline L. confusus & 7 & 7.7 & - & - & - & - \\
\hline L. cellobiosus & 9 & 10 & - & - & - & - \\
\hline L. lactis subsp. lactis & 4 & 4.4 & 18 & 13.8 & 5 & 4 \\
\hline E. faecalis & 6 & 6.6 & 13 & 10 & 8 & 6.5 \\
\hline E. faecium & 14 & 15.5 & 9 & 7 & 17 & 13.8 \\
\hline E. durans & 9 & 10 & 11 & 8.4 & 6 & 4.8 \\
\hline Unidentified lactococci & 12 & 13.8 & 21 & 16.3 & 8 & 6.5 \\
\hline Unidentified lactobacilli & 8 & 8.8 & 16 & 12.3 & 12 & 9.7 \\
\hline Total & 90 & & 130 & & 123 & \\
\hline
\end{tabular}

Table 4

Physiological and biochemical characteristics of lactic acid bacteria isolates ${ }^{a}$

\begin{tabular}{|c|c|c|c|c|c|c|c|}
\hline \multirow[b]{2}{*}{ Growth at or in: } & \multicolumn{7}{|c|}{ Tests } \\
\hline & 1 & 2 & 3 & 4 & 5 & 6 & 7 \\
\hline $10^{\circ} \mathrm{C}$ & - & + & - & + & + & + & + \\
\hline $15^{\circ} \mathrm{C}$ & + & + & + & + & + & + & + \\
\hline $37^{\circ} \mathrm{C}$ & $\mathbf{v}$ & + & - & + & + & + & + \\
\hline $45^{\circ} \mathrm{C}$ & $\mathbf{v}$ & - & - & + & - & + & + \\
\hline $4 \% \mathrm{NaCl}$ & + & + & + & + & + & - & + \\
\hline $6.5 \% \mathrm{NaCl}$ & + & - & - & + & - & + & + \\
\hline $8 \% \mathrm{NaCl}$ & - & - & - & + & - & + & + \\
\hline $\mathrm{pH} 9.6$ & - & - & - & - & - & + & + \\
\hline $\mathrm{pH} 3.9$ & + & - & - & - & - & - & - \\
\hline Lactic acid isomer & $\mathrm{L}(+)$ & $\mathrm{L}(+)$ & $\mathrm{L}(+)$ & $\mathrm{L}(+)$ & $\mathrm{L}(+)$ & $\mathrm{L}(+)$ & $\mathrm{L}(+)$ \\
\hline Citrate & - & + & - & + & + & - & - \\
\hline Acetoin & - & + & - & + & - & - & - \\
\hline Arginine hydrolysis & - & - & - & - & + & - & - \\
\hline Survival at $60^{\circ} \mathrm{C}$ for $30 \mathrm{~min}$ & - & - & + & - & - & + & + \\
\hline CO2 from glucose & - & - & - & - & - & - & - \\
\hline \multicolumn{8}{|l|}{ API 50 CH-Syst. } \\
\hline Esculin & + & + & - & + & - & + & + \\
\hline Lactose & + & + & - & + & - & + & + \\
\hline Galactose & + & + & + & + & + & + & + \\
\hline Fructose & + & + & + & $\mathbf{N}$ & + & + & + \\
\hline Sorbitol & + & + & + & + & - & - & - \\
\hline Mannose & + & + & + & + & + & + & + \\
\hline Melibiose & + & + & + & $\mathbf{N}$ & + & - & - \\
\hline Cellobiose & - & + & + & - & + & & - \\
\hline Raffinose & + & + & + & + & + & - & - \\
\hline Xylose & + & + & + & + & + & - & - \\
\hline Sucrose & + & - & - & + & - & + & + \\
\hline Arabinose & - & - & - & + & + & - & + \\
\hline Melezitose & + & + & + & + & - & - & - \\
\hline Number of strains & 41 & 3 & 27 & 75 & 27 & 27 & 66 \\
\hline
\end{tabular}

a: All strains examined were gram-positive, motility-negative and catalase negative.

+: positive result; -: negative result

1. L. casei, 2. L. rhamnosus, 3. L. paracasei, 4. L. plantarum ,5. L. lactis subsp. lactis, 6. E. faecalis, 7. E. faecium. 
Yeasts were isolated from all samples on potato dextrose agar plates. Of the 32 isolates, 22 were identified Saccharomyces genus because they reproduced by multilateral budding, formed pseudohyphae and asci containing one to four globose ascospores, fermented glucose, galactose and maltose; they did not assimilate lactose or nitrate and their cells were globose to subglobose or ellipsoidal to cylindrical. The other ten isolates seemed to belong to the genus Candida; they reproduced by multilateral budding, they did not form ascospores or carotenoid pigment, and their cells were ovoid or ellipsoidal to cylindrical.

All of these characteristics, together with the API 20C AUX system (Bio Merieux, S.A.) pattern of biochemical tests, identified the 22 isolates as Saccharomyces cerevisiae and the 10 other isolates as Candida parapsilosis. The strains of these two species of yeasts were isolated in all stages of olive fermentation.

Of the 18 CFB tested by the well diffusion method, 9 showed an ability to stimulate the growth of 17 strains of $L$. plantarum among the 70 isolated and tested in this study. A demonstration of the stimulation exhibited by CFB towards $L$. plantarum S33 is shown in Figure 1. On the other hand, all the CFB tested were not active with $L$. casei, $L$. rhamnosus, L. paracasei, L. confusus, L. cellobiosus, L. lactis subsp. lactis, E. faecalis, E. faecium, E. durans strains isolated in this study. This is a new finding since the brine solutions from olive fermentation to stimulate $L$. plantarum growth have not been reported before.

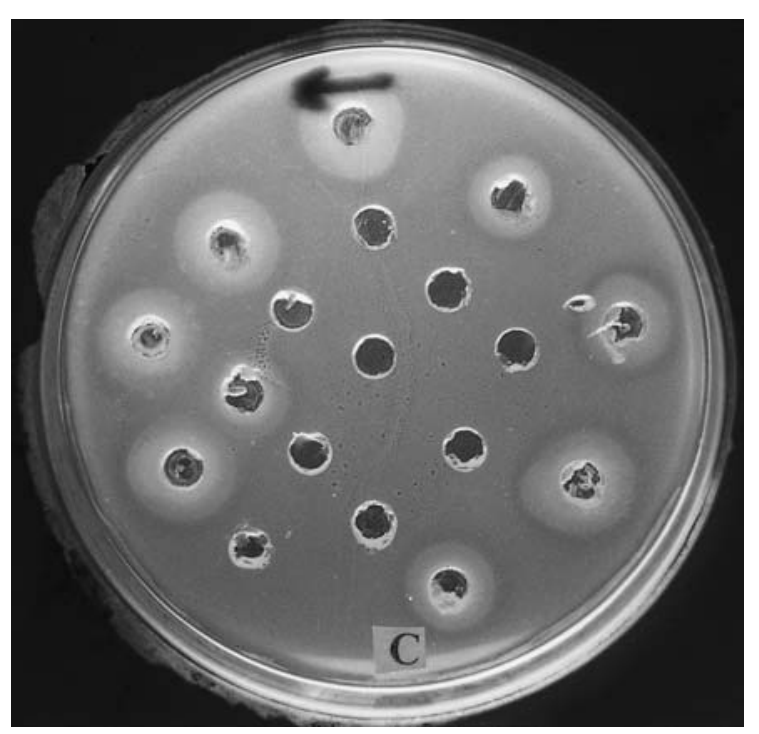

Figure 1

Agar well diffusion method showing the action of brine solutions (CFB) on L. plantarum S33.

Brine solution samples (CFB) were placed into the wells. The plates were incubated for 5 days at $22^{\circ} \mathrm{C}$, and examined for turbid zones around the wells indicating the stimulation of L. plantarum S33 growth.

\section{DISCUSSION}

Results indicate that the naturally fermented Algerian olives reveal a diversity of microflora. This diversity could be linked to the $\mathrm{pH}$ variations throughout the different stages of fermentation. The significant decrease in $\mathrm{pH}$ during the second $(\mathrm{pH}$ 4.53) and the third ( $\mathrm{pH} 4.40)$ stages of fermentation may be considered consequence of acid production by the increasing microbial populations.

Levels of most lactic acid bacteria, and yeasts increased during the 60 and 90 days of fermentation, when coliforms, staphylococci and lipolytic bacteria decrease their growth, probably due to the combined inhibitory effect of $\mathrm{pH}$ and brine concentration (Litopoulou-Tazanetaki, 1977).

In this study, the first stage of fermentation (15 days) was characterized by the growth of rather heterogeneous microflora, including aerobic bacteria, coliforms, staphylococci, lactic acid bacteria, lactobacilli, enterococci, psychrotrophs, lipolytic bacteria and yeasts. At the second stage (60 days) lactic acid bacteria and yeast population outnumbered the initial heterogeneous bacterial flora. Finally, at the third stage (90 days), $L$. plantarum population became dominant (31.7\%) and persisted throughout the fermentation together with yeast populations (Saccharomyces cerevisiae and Candida parapsilosis), so that L. plantarum can be considered the dominant species in naturally fermented Algerian olives. In similar works, de la Borbolla y Alcalá (1971), Fernández Gonzalez et al. (1993), Ruiz-Barba and Jiménez-Díaz (1995) and Harris (1998) reported that the indigenous lactic acid bacteria change spontaneously during natural olive fermentation. At the end of the process only $L$. plantarum and yeasts were detected. Asehraou et al. (2002) described similar results in fermenting green olives that had been inoculated with $L$. plantarum. In contrast, Randazzo et al. (2004) found that about $50 \%$ of the isolated strains from naturally fermented Sicilian green olives belonged to the $L$. casei species.

Two species of yeasts (Saccharomyces cerevisiae and Candida parapsilosis) were isolated from the three stages of fermented olives. This result is not in complete agreement with those reported by Ruiz-Barba and Jimenez-Diaz (1995) who detected strains of Saccharomyces cerevisiae, Candida parapsilosis and other species of yeasts during the first stage of the fermentation. The same authors reported that Saccharomyces cerevisiae and Candida parapsilosis appeared very early in the olive brine and seemed to be well adapted to the first stage of fermentation.

An interesting question concerns the presence and persistence of $L$. plantarum and other lactic acid bacteria together with yeasts at the third stage of fermentation. However, the initial heterogeneous bacterial flora decreased during the fermentation process. In our study we demonstrated that brine solutions obtained at the end of fermentation have the capacity to stimulate several L. plantarum 
strains. We have not established, however, the nature of this stimulatory factor (s). Tests to determine the nature of this stimulatory agent (s) will follow its purification.

Several authors described an increase in the vitamin content of products that had undergone a lactic acid bacteria fermentation (Akinrele, 1970; McFeeters, 1988). In most cases, this production of vitamins has been attributed to the activity of different microorganisms growing together with $e$ lactic acid bacteria during fermentation (Costilow and Fabian, 1953a, 1953b; Rosen and Fabian, 1953). Ruiz-Barba and Jimenez-Diaz (1995) reported that several yeast strains were able to produce large amounts of different vitamins in a laboratory medium. These authors found some indications supporting the idea that these vitamins are produced by yeasts during fermentation.

At present, several brine solutions are being further investigated in our laboratory to characterize and identify the stimulating factors present in these solutions. More recently, we have reported a new proteinaceous bioactive substance, which stimulates the growth of several L. plantarum strains previously isolated from naturally fermented green olives (Kacem et al., 2004a). This factor named "Stimulin" (Kacem et al., 2004b) is produced by strains of lactococci isolated from $L b e n$, a naturally fermented milk produced in Algeria.

On the other hand, our study indicated that low incidences of coliforms, staphylococci, psychrotrophs or lipolytic bacteria were detected at the end of fermentation. Probably, the growth of these bacteria must be restricted by brine acidification (the $\mathrm{pH}$ of the brine solution was 4.40 at the end of fermentation) and a bacteriocin produced by lactic acid bacteria (in particular, L. plantarum strains): as we know, some strains of $L$. plantarum isolated from fermented olives produce inhibitory substances, such as bacteriocins (Jiménez-Díaz et al., 1993; Delgado et al., 2001 and Maldonado et al., 2003, Kacem et al., 2005).

From the results presented here, it is clear that lactic acid bacteria represented by $L$. casei, $L$. rhamnosus, L. paracasei, L. plantarum, L. confusus, L. cellobiosus, L. lactis subsp. lactis, E. faecalis, E. faecium, $E$. durans were isolated at different stages of the spontaneous fermentation of green olives produced in western Algeria. L. plantarum was the major species isolated in this study. Similar results have been reported in the literature (FernándezDíez, 1983; Ruiz-Barba et al., 1994; Van Den Berg et al. 1993; Lavermicocca et al., 1998, 2002; Randazzo et al., 2004, Kacem et al., 2004a).

$E$. faecalis and $L$. lactis subsp. lactis species were also isolated in this study. Enterococcus genus, a frequent contaminant in olives has been isolated from green olive fermentations (Floriano et al., 1998). Isolates have been identified, characterized and utilized with $L$. pentosus as starter cultures for Spanish-style green olive fermentation (de Castro et al., 2002).

Concerning L. lactis subsp. lactis, this bacterium is occasionally isolated from fresh olives
(Korukluoglu et al., 2002), olive oil (Kacem et al., 2003) or fermented olives (Kacem et al., 2004a) but has not ever before been reported as being related to olive fermentation.

\section{CONCLUSION}

The aim of this work was to gain a comprehensive view of the microbiological characteristics of naturally fermented green olives produced in Western Algeria during fermentation.

The results from this work show a significant presence of different microbial groups after 15 and 60 days of fermentation. At the end of fermentation, lactic acid bacteria (essentially L. plantarum) and yeasts (Saccharomyces cerevisiae and Candida parapsilosis) predominate over the other microbial groups.

Different species of lactic acid bacteria and yeasts present in this product were isolated and identified on the basis of morphological and biochemical criteria. The characterization of isolates based on a microscopic analysis and phenotypic characteristics (especially biochemical properties and sugar fermentation abilities) is very useful and remains the most widely recognized approach but it would be interesting to conduct a more detailed study on bacterial identification using molecular methods. Experiments concerning molecular identification of these bacteria are in progress.

At the same time, current research in our laboratory is aimed at studying the interactions (inhibition or stimulation) between $L$. plantarum strains and yeasts in laboratory media as well as in brined olive juice. This would allow us to select the best combinations of yeasts and $L$. plantarum strains to use them as starters in the fermentation of Algerian fermented olives with the flavor and sensorial qualities desired by consumers.

\section{ACKNOWLEDGEMENTS}

This study was supported by a grant of the "Ministère de l'Enseignement Supérieur" of Algeria (Project: F3101/04/97) and a grant of ANDRS (Project: 02/12/01/99038).

\section{REFERENCES}

Akinrele IA. (1970). Fermentation studies on maize during the preparation of a traditional African starch-cake food. J Sci Food Agri 21, 619-625.

Anonymous (2000). Statistiques Agricoles, 1990-1999. Série B, Superficie et production. ONS (Office National des Statistiques), Algers, Algeria.

Asehraou A, Peres C, Brito D, Faid M and Serhrouchni M. (2000). Characterization of yeast strains isolated from bloaters of fermented green table olives during storage. Grasas y Aceites 51, 225-229.

Asehraou A, Peres C, Faid M and Brito D. (2002). Reducing the bloater spoilage incidence in fermented 
green olives during storage, Grasas y Aceites 53, 330-334.

Barnett JA, Payne RW and Yarrow D. (1990). Yeasts: characteristics and identification. C. U. Press Syndicate of the University of Cambridge, Cambridge.

Borcakli M, Ozay G and Alperden I. (1993). Fermentation of Turkish olives with traditional and aerated systems. In Food flavours, ingredients, and composition, (Ed.), Elvesier Science Publisher, BV, Charalambous, pp. 265-277.

Catulo L, Leitão F, Silva S, Oliveira MM, Peres C, Gomes $M L$ and Fernandes I. (2002). Table olive fermentation of galega portuguese variety Microbiological, physicochemical and sensorial aspects IV International Symposium on olive growing. Acta Hort (ISHS) $\mathbf{5 8 6}$ 611-615.

Costilow RN and Fabian FW. (1953a). Availability of essential vitamins and amino acids for Lactobacillus plantarum in cucumber fermentations. Appl Microbiol 1(6), 320-326.

Costilow RN and Fabian FW. (1953b). Effect of various microorganisms on the vitamin and amino acid content of cucumber brines. Appl Microbiol 1(6), 327329.

Detro A, Montaño A, Casado FJ, Sánchez, AH and Rejano L. (2002). Utilization of Enterococcus casseliflavus and Lactobacillus pentosus as starter cultures for Spanish-style green olive fermentation. Food Microbiol 19, 637-644.

De la Borbolla y Alcalá JMR, González Cancho F and González Pellisó F. (1971). Aceitunas verdes y de color cambiante en salmuera. I. Grasas y Aceites 22, 455-460.

De Man JC, Rogosa M and Sharpe ME. (1960). A medium for the cultivation of lactobacilli. J Appl Bacteriol 23, 130-135.

Delgado A, Brito D, Fevereiro P and Marques JF (2001). Antimicrobial activity of $L$. plantarum, isolated from a traditional lactic acid fermentation of table olives. Lait 81, 203-215.

Devriese LA, Van de Kerckhove A, Kilpper-Bälz R and Schleifer KH. (1987). Characterization and identification of Enterococcus species isolated from the intestines of animals. Int J Syst Bacteriol 37, 257-259.

Fernández-Díez MJ (1983). Olives p. 379-397. In G. Reed (ed.), Food and feed production with microorganisms. Verlag Chemie, Deerfield Beach, Fla.

Fernández González MJ, García García P, Garrido Fernández A and Durán Quintana MC. (1993). Microflora of the aerobic preservation of directly brined green olives from Hojiblanca cultivar. J Appl Bacteriol 75, 226-233.

Floriano B, Ruiz-Barba JL and Jiménez-Díaz R. (1998). Purification and genetic characterization of enterocin I from Enterococcus faecium $6 \mathrm{~T} 1 \mathrm{a}$, a novel antilisterial plasmid-encoded bacteriocin which does not belong to the pediocin family of bacteriocins. Appl Environ Microbiol 64, 4883-4890.

Fricourt BV, Barefoot SF, Testin RF and Hayasaka SS. (1994). Detection and activity of plantaricin F, an antibacterial substance from Lactobacillus plantarum BF001 isolated from processed channel catfish. J Food Pro 57, 698-702.

Garcia MC, Otero A, Garcia ML, and Moreno B. (1987). Microbiological quality and composition of two types of Spanish sheep's milk cheeses (Manchego and Burgos varieties). J Dairy Res 54, 551-557.

Harris LJ. (1988). The microbiology of vegetable fermentations. In Wood, BJB. (Ed.), Microbiology of
Fermented Foods, vol.1, Blackie Academic and Professional, London, pp. 45-72.

Jiménez-Díaz R, Rios-Sanchez RM, Desmazeaud M, Ruiz-Barba JL and Piard JC. (1993). Plantaricins S and $\mathrm{T}$, two new bacteriocins produced by Lactobacillus plantarum LPCO10 isolated from a green olive fermentation. Appl Environ Microbiol 59, 1416-1424.

Kacem M, Zadi-Karam H and Karam N. (2003). Lactic acid bacteria of western Algeria. I: Characteristics of strains isolated from raw milk and olive oil, Sciences et Technologie (Université de Constantine, Algérie) 20, 45-50.

Kacem M, Zadi-Karam H and Karam N. ( 2004a). Isolation of lactic acid bacteria for its possible use in the fermentation of green algerian olives. Grasas $y$ Aceites 55, 385-393.

Kacem M, Zadi-Karam H and Karam N. (2004b) "Stimulin" a new factor produced by lactococci isolated from Iben and its effect on Lactobacillus plantarum growth. Quatrième Journées biotechnologiques. Association Tunisienne de biotechnologie (AT Biotech), Hammamet, 19-22 décembre 2004, Tunisie.

Kacem M, Zadi-Karam H and Karam N. (2005). Detection and activity of plantaricin OL15 a bacteriocin produced by Lactobacillus plantarum OL15 isolated from Algerian olives. Grasas y Aceites 56, 192-197.

Kandler O and Weiss N. (1986). Regular, nonsporing gram-positive rods, p. 1208-1234. In P. H. A. Sneath (ed), Bergey's manual of systematic bacteriology, vol 2. Williams and Wilkins, Baltimore, Md.

Kempler GM and Mc Kay LL. (1980). Improved medium for detection of citrate-fermenting Streptococcus lactis subsp. diacetylactis. Appl Environ Microbiol 39, 926-927.

Korukluoglu M, Gurbuz O and Sahin I. (2002). Identification of lactic acid bacteria in fresh olive microflora (Turkish). Turkish Journal of Biology 8, 109113.

Kreger-van Rij NJW. (1984). "Yeasts". Third revised and enlarged edition, Elsevier Science Publishers Amsterdam.

Lavermicocca P, Gobbetti M, Corsetti A and Caputo L. (1998). Characterization of lactic acid bacteria isolated from olive phylloplane and table olive brines. Ital J Food Sci 10, 27-39.

Lavermicocca P, Valerio F, Lonigro SL, Gobbetti M, Baruzzi $F$ and Morea M. (2002). Olive fermentations using lactic acid bacteria isolated from olive phylloplane and olive brines. IV International Symposium on olive growing . Acta Horticulturae (ISHS) 586, 621-624.

Litopoulou-Tazanetaki E. (1977). Staphylococci and micrococci in Kefalotyri cheese. Milchwissenschaft 32, 211-214.

Maldonado A, Ruiz-Barba JL and Jiménez-Díaz R. (2003). Production of plantaricin NC8 by Lactobacillus plantarum NC8 is induced in the presence of different types of gram-positive bacteria. Arch Microbiol 181, 8-16.

McFeeters RF. (1988). Effects of fermentation on the nutritional properties of food. In E karmas and RS Harris (ed.), Nutritional evaluation of food processing. Van Nostrand Reinhold Co, New York, pp. 423-446.

Mundt JO. (1986). Lactic acid streptococci, p. 1065-1066 In P. H. A. Sneath, et al. (ed), Bergey's manual of systematic bacteriology, vol 2. The Williams \& Wilkins Co., Baltimore, Md.

Oliveira M, Brito D, Catulo L, Leitão F, Gomes L, Silva S, Vilas Boas L, Peito A, Fernandes I, Gordo F and Peres C. (2004). Biotecnología de la fermentación de 
aceitunas de la variedad portuguesa 'Galega'. Grasas y Aceites 55, 219-226.

Randazzo CL, Restuccia C, Romano AD and Caggia C. (2004). Lactobacillus casei, dominant species in naturally fermented Sicilian green olives. Int J Food Microbiol 90, 9-14.

Rogosa M, Mitchell JA and Wiseman RF. (1951). A selective medium and enumeration of oral and faecal lactobacilli. J Bacteriol 62, 132-133.

Rogosa M, Franklin JG and Perry KD. (1961). Correlation of the vitamin requirements with cultural and biochemical characters of Lactobacillus spp. J Gen Microbiol 25, 473-482.

Rosen S and Fabian FW (1953). The importance of biotin, niacin and pantothenic acid in cucumber fermentation. Food Technol 7, 244-247.

Ruiz-Barba JL, Piard JC and Jiménez-Díaz R. (1991). Plasmid profiles and curing of plasmids in Lactobacillus plantarum strains isolated from green olive fermentation. J Appl Bacteriol 71, 417-421.

Ruiz-Barba JL, Cathcart DP, Warner PJ and JiménezDíaz R. (1994). Use of Lactobacillus plantarum LPCO10, a bacteriocin producer, as a starter culture in spanish-style green olive fermentations. Appl Environ Microbiol 60, 2059-2064.

Ruiz-Barba JL and Jiménez-Díaz R. 1994. Vitamin and amino acid requirements of Lactobacillus plantarum strains isolated from green olive fermentations. J Appl Bacteriol 76, 350-355.
Ruiz-Barba JL and Jiménez-Díaz R. 1995. Availability of essential B-group vitamins to Lactobacillus plantarum in green olive fermentation brines. Appl Environ Microbiol 61, 1294-1297.

Samelis J, Maurogenakis F and Metaxopoulos J. (1994). Characterisation of lactic acid bacteria isolated from naturally fermented Greek dry salami. Int J Food Microbiol 23, 179-196.

Steel RGD and Torrie JH. (1980). Principles and procedures of statistics. $2^{\text {nd }}$ ed McGraw-Hill, New York. Terzaghi BE and Sandine WE. (1975). Improved medium for lactic streptococci and their bacteriophages. Appl Microbiol 29, 807-813.

Thomas TD. (1973). Agar medium for differentiation of Streptococcus cremoris from other bacteria. NZJ Dairy Sci Technol 8, 70-71.

Van Den Berg DJC, Smits A, Pot B, Ledeboer AM, Keresters K, Verbakel JMA and Verrips CT. (1993). Isolation, screening and identification of lactic acid bacteria from traditional food, fermentation processes and culture collection. Food Biotechnol. 7, 189-205.

Zourari A, Roger S, Chabanat C. and Desmazeaud M. (1991). Caractérisation de bactéries lactiques thermophiles isolées de yaourts artisanaux grecs. Souches de Streptococcus salivarius subsp. thermophilus. Lait 71, 445-461.

Recibido: Febrero 2005 Aceptado: Febrero 2006 